\title{
EVALUATION OF ANTIOXIDATIVE, PROTEOLYTIC, AND ACE INHIBITORY ACTIVITIES OF POTENTIAL PROBIOTIC LACTIC ACID BACTERIA ISOLATED FROM TRADITIONAL FERMENTED FOOD PRODUCTS
}

\author{
P.N. ThakKar ${ }^{a, c}$, A.R. Patel ${ }^{b *}$, H.A. Modi ${ }^{a}$ and J.B. Prajapati \\ ${ }^{a}$ Department of Life Sciences, Gujarat University, Ahmedabad. India \\ ${ }^{\mathrm{b}}$ Division of Dairy and Food Microbiology, Mansinhbhai Institute of Dairy \& Food Technology-MIDFT, Mehsana. \\ India \\ ${ }^{\mathrm{c}}$ Department of Dairy Microbiology, SMC College of Dairy Science, Anand Agriculture University, Anand. India
}

(Received: 20 June 2017; accepted: 23 August 2017)

\begin{abstract}
Probiotic lactic acid bacteria (LAB) have been engrossed in plentiful food fermentations, known to man for millennia. The current investigation was aimed at investigating technical attributes, such as production of bioactive peptides, particularly ACE-I activity (anti-hypertensive property), proteolytic activity, and antioxidant activities of the potential probiotic LAB strains isolated from a diverse dairy and non-dairy based fermented foods. Among all ten $\mathrm{LAB}$ isolates, PFC21, isolated from sauerkraut, exhibited the highest antioxidative potential and showed maximum free radical scavenging ability using both ABTS (83.8 $\pm 3.77 \%)$ and DPPH $(59.4 \pm 2.18 \%)$ assays. It was followed by PD2 (dosa batter isolate) that showed (79.4 $1.61 \%$ ) activity in ABTS assay. PD2 revealed the highest proteolytic activity during $24 \mathrm{~h}$ and $48 \mathrm{~h}$ (with 0.82 and 1.12 absorbance, respectively) of fermentation at $37{ }^{\circ} \mathrm{C}$; followed by a curd isolate, PC6, and PFC21 with 0.99 and 0.90 absorbance, respectively, at $48 \mathrm{~h}$ incubation. Furthermore, PD2 also showed the significantly $(\mathrm{P}<0.05)$ highest $(49.39 \%)$ ACE inhibition followed by PFC21 $(41.38 \%)$. These fascinating results led us to further evaluate the potential probiotic strains with regard to their utilization in the production of healthy quality foods with additional technical advantages.
\end{abstract}

Keywords: probiotics, antioxidative potential, bioactive peptide, angiotensin-converting-enzyme (ACE) inhibition

The growing attention to understand the role of food in human health has budged it from its primary role as a source of energy to the subtle action of biologically dynamic food components for wellbeing. Henceforth, there is a growing demand for functional foods at present. In India, variety of dairy and non-dairy fermented foods are known and consumed by large population as a part of their daily diet, but their probiotic role had not been investigated widely. Incorporation of probiotic microorganisms isolated from various regional fermented food products in market can positively enhance health status of larger segment of communities.

Reactive oxygen species (ROS) mediated oxidative damage of vital cell components is known to play crucial role in the development of chronic diseases such as diabetes mellitus, cancer, heart disease, Alzheimer, cataract, and aging (Mishra et al., 2015). It occurs as a result of imbalance between the generation of oxygen derived radicals and the antioxidant potential of the organism. Bioactive peptides produced from LAB through enzymatic hydrolysis and/or microbial proteolysis during milk fermentation are known to possess

\footnotetext{
* To whom correspondence should be addressed.

Phone: +91-2762243777; fax: +91-02762-253422; e-mail: amiamipatel@yahoo.co.in
} 
oxidative inhibitory capacity due to their ability to scavenge free radicals (VIRTANEN et al., 2007). Strains of LAB may reinforce the inherent cellular antioxidant defence by secretion of enzymes like superoxide dismutase (SOD) or promote production of the major non-enzymatic antioxidant and free radical scavenger glutathione (GSH). Currently, synthetic antioxidants like butylated hydroxyanisole (BHA) and butylated hydroxytoluene (BHT) have limited use because of their suspected carcinogenic potential and thus, there is a shift towards the use of natural antioxidants (СнтоuRou et al., 2011). Recent studies suggest that probiotics may have a potential therapeutic role in ROS characterized gastrointestinal disorders (SPYROPOULOS et al., 2011).

Proteolysis is the most important biochemical process that occurs in cultured milk products during fermentation and storage; resulting in the release of bioactive peptides from specific amino acid sequences within the parent milk proteins that can provide physiological benefits (YoshiKawa et al., 2000). During fermentation, milk proteins get hydrolysed by LAB proteinases and peptidases resulting in an enhanced quantity of free amino groups and various forms of peptides (KHolif et al., 2011). Generally, the extent of proteolysis varies among strains and is time as well as strain dependent (DonKor et al., 2007).

Fermented milks are excellent sources of bioactive peptides owning specific physiological roles like antibacterial, anticancer, and antihypertensive activities. Among these, the antihypertensive peptides or Angiotensin converting enzyme inhibitors (ACE-I) are the most broadly studied. ACE inhibitory peptides have been isolated from a variety of fermented dairy products including cheeses, fermented milks, and yoghurts (FITZGERALD \& MeISEL, 2000), and these bioactive peptides could serve as healthier and natural alternatives of ACE-I drugs (Donkor et al., 2007).

Strains of LAB used in current study have shown potential probiotic candidature in earlier investigations (THAKKAR et al., 2015). Hence, in addition to the claimed health benefits of probiotics, the present investigation was principally aimed to determine the technical attributes of these potential probiotic $\mathrm{LAB}$ isolates, including production of bioactive peptides, particularly ACE-I activity, proteolytic activity, and antioxidant activities.

\section{Materials and methods}

\subsection{Source of cultures}

Total 10 test strains of LAB, i.e. PD2, PD11, PD30 (Dosa batter); PC6, PC27 (Curd); PH5 (Handva batter); PJ5, PJ29 (Jilebi batter); PSC6 (Soycurd); and PFC21 (Fermented cabbage) were transferred to MRS broth for propagation prior to experiments. The stock cultures were prepared in glycerol $(80 \%)$ and preserved in $-20^{\circ} \mathrm{C}$. All microbiological media and chemicals were procured from HiMedia (Mumbai, India). These isolates were subjected to species level biochemical identification based on their carbohydrate fermentation profile using API test stripes (Table 1).

\subsection{Antioxidant activity}

The antioxidant activity was evaluated by two different assays, ABTS and DPPH, making the use of cell free extract of overnight grown culture. BHT and vitamin C (ascorbic acid) were used as synthetic and natural standards $\left(100 \mu \mathrm{g} \mathrm{ml}^{-1}\right)$. 
Table 1. Details of selected LAB strains

\begin{tabular}{lllc}
\hline LAB isolate & Isolation source & \multicolumn{1}{c}{ Carbohydrate fermentation (API Kit) } \\
\cline { 3 - 4 } & & Species identity & \% similarity \\
\hline PD2 & Dosa batter & L. rhamnosus & 99.8 \\
PD11 & Dosa batter & L. casei & 99.9 \\
PD30 & Dosa batter & L. plantarum & 88.6 \\
PC6 & Curd & L. casei & 99.8 \\
PC27 & Curd & L. fermentum & 99.8 \\
PH5 & Handva batter & L. fermentum & 97.4 \\
PJ5 & Jilebi batter & E. faecium & 99.8 \\
PJ29 & Jilebi batter & E. faecium & 95.9 \\
PSC6 & Soycurd & L. rhamnosus & 99.9 \\
PFC21 & Fermented cabbage & L. fermentum & 99.9 \\
\hline
\end{tabular}

1.2.1. ABTS [2, 29-Azinobis (3-ethylene benzothiazoline) 6-sulphonic acid] assay. In this method, the total radical scavenging capacity is based on ability of a compound to scavenge the stable ABTS radical in 10 min (RE et al., 1999). The ABTS working solution was prepared by mixing $88 \mu \mathrm{l}$ of $140 \mathrm{mM}$ potassium persulphate with $5 \mathrm{ml}$ of $7 \mathrm{mM}$ ABTS stock solution followed by overnight incubation in dark bottles for generation of radicals. Then it was diluted with phosphate buffer saline (PBS) to adjust the absorbance at $734 \mathrm{~nm}$ to $(0.7 \pm 0.02)$. An aliquot of $10 \mu \mathrm{l}$ of product supernatant, collected after centrifugation at $10000 \mathrm{~g}$ for $30 \mathrm{~min}$, was transferred into 96 wells micro plate and to that $100 \mu \mathrm{l}$ of ABTS in PBS solution was added and mixed for $10 \mathrm{sec}$. The decrease in the absorbance at $734 \mathrm{~nm}$ was recorded over the period of $10 \mathrm{~min}$ at $10 \mathrm{sec}$ interval using Multiplate reader. The free radical scavenging activity (\%) was calculated by the following equation; where 'blank' means ABTS solution and PBS without sample:

$\%$ Scavenging activity $=\left\{\left(\mathrm{A}_{734 \mathrm{~nm}}\right.\right.$ blank $-\mathrm{A}_{734 \mathrm{~nm}}$ sample $) /\left(\mathrm{A}_{734 \mathrm{~nm}}\right.$ blank $\left.)\right\} \times 100$

1.2.2. $D P P H[2,2$ diphenyl-1-picrylhydrazyl] assay. The antioxidant activity from the extracts of products (fermented milk made from each isolate) was analysed through modified DPPH method (HATI et al., 2013). Hundred $\mu 1$ of the product supernatant from an appropriate dilution, collected after centrifugation at $10000 \mathrm{~g}$ for $30 \mathrm{~min}$, was loaded into 96 wells micro plate, mixed with $100 \mu \mathrm{l}$ of freshly prepared DPPH solution, and incubated in dark for $120 \mathrm{~min}$ at $37^{\circ} \mathrm{C}$ after covering the micro plate with aluminium foil. The absorbance of the solution was measured at $517 \mathrm{~nm}$ against methanol using Multiplate reader. The experiment was performed in triplicates and the results were expressed as below; where 'blank' means DPPH solution and PBS without sample:

$\%$ Scavenging activity $=\left\{\left(\mathrm{A}_{515 \mathrm{~nm}}\right.\right.$ blank $-\mathrm{A}_{515 \mathrm{~nm}}$ sample $) /\left(\mathrm{A}_{515 \mathrm{~nm}}\right.$ blank $\left.)\right\} \times 100$

\subsection{Proteolytic activity}

The degree of proteolysis during the fermentation of milk was quantified by measuring free amino (NH2-) groups using o-phthalaldehyde (OPA) method (DonKor et al., 2005). Three ml curd samples were added to $3 \mathrm{ml}$ of $1 \%(\mathrm{w} / \mathrm{v})$ trichloroacetic acid (TCA). The suspension was vortexed and vacuum filtered using Whatman filter paper. One hundred and fifty microlitres 
of TCA soluble peptides was added to $3 \mathrm{ml}$ of OPA reagent, and after 2 min of incubation $\left(20 \pm 1{ }^{\circ} \mathrm{C}\right)$, the absorbance was measured at $340 \mathrm{~nm}$ with using Systronic PC based double beam spectrophotometer (model:2202), India. The experimental procedure was repeated with untreated reconstituted skim milk (RSM) as a control. A relative degree of proteolysis was determined as the difference between the free amino groups in fermented milk and untreated milk with respect to their OD values.

\subsection{ACE-inhibitory activity}

ACE inhibitory activity was determined according to the technique of CHEUNG (1971) with a little modification (PAPADIMITRIOU et al., 2007). Active cultures were inoculated into a 10\% reconstituted skim milk (at the rate of $2 \%$ ), incubated for $24 \mathrm{~h}$, and fermented milk was centrifuged at $10000 \mathrm{~g}$ for $10 \mathrm{~min}$ at $4{ }^{\circ} \mathrm{C}$ (Eppendorf Centrifuge, US). The supernatant was collected and filtered through $0.2 \mu \mathrm{m}$ cellulose acetate membrane filter. Thereafter, $50 \mu \mathrm{l}$ of $5 \mathrm{mM}$ HHL (hippuryl-L-histidyl-L-leucine) (10.74 $\mathrm{mg} \mathrm{HHL}$ in $5 \mathrm{ml}$ sodium borate buffer, $\mathrm{pH}$ 8.3) solution was mixed with $500 \mu \mathrm{l}$ deionized water and $100 \mu \mathrm{l}$ of sample (filtrate). The reaction was initiated by the addition of $20 \mu \mathrm{l}(4 \mathrm{mU}$ in $250 \mu \mathrm{l})$ of ACE enzyme and the mixture was incubated for $30 \mathrm{~min}$ at $37^{\circ} \mathrm{C}$. The reaction was terminated by the addition of $1000 \mu \mathrm{l}$ of $1 \mathrm{M} \mathrm{HCl}$. The hippuric acid liberated by the ACE was extracted with $1.7 \mathrm{ml}$ ethyl acetate and then heated at $100{ }^{\circ} \mathrm{C}$ for $20 \mathrm{~min}$ in water bath. The residues containing hippuric acid were dissolved in $2 \mathrm{ml}$ of deionized water and the absorbance of the solution was measured spectrophotometrically at $250 \mathrm{~nm}$ against blank. The extent of inhibition was calculated as follows.

where,

$$
\% \text { ACE Inhibitory activity }=\{1-\mathrm{C}-\mathrm{D}) /(\mathrm{A}-\mathrm{B})\} \times 100(\%)
$$

A: the absorbance of solution containing ACE but no sample

$\mathrm{B}$ : the absorbance of solution containing ACE but no sample and $\mathrm{HCl}$

$\mathrm{C}$ : the absorbance of solution containing ACE, sample and $\mathrm{HCl}$

D: the absorbance of solution containing ACE, sample but no $\mathrm{HCl}$

The extent of inhibition is estimated as the concentration of the component that inhibits $50 \%$ of ACE activity (IC50) under the given conditions (DonKor et al., 2007).

\subsection{Statistical analysis}

The results of three individual experiments were gathered to generate the mean \pm standard deviation (SD). One-way analysis of variance (ANOVA) was used to determine the significance by using Minitab at $\mathrm{P}<0.05$.

\section{Results and discussion}

India is a country of rich microbial diversity with an array of food habits. Fermented foods have been a regular part of meal for most Indians and have also been well known for its extended shelf life.

\subsection{Antioxidant activity}

Total antioxidative potential of ten lactobacilli cultures were determined by ABTS assay and DPPH assay; results were expressed in terms of percentage (\%) activity (Table 2). The 
scavenging ability of the cell free extracts of the probiotic strains were compared with the standard antioxidants, ascorbic acid (vit. C), and BHT.

Table 2. Antioxidant activity of LAB isolates by ABTS and DPPH methods

\begin{tabular}{lcc}
\hline Isolate no. & \multicolumn{2}{c}{ \% Inhibition (24 h incubation) } \\
\cline { 2 - 3 } & ABTS method & DPPH method \\
\hline PD2 & $79.4 \pm 1.61 a$ & $49.9 \pm 1.38 d$ \\
PD11 & $42.1 \pm 2.72 d$ & $28.7 \pm 1.47 f$ \\
PD30 & $60.9 \pm 1.83 c$ & $35.6 \pm 1.06 e f$ \\
PC6 & $56.8 \pm 3.15 c$ & $41.7 \pm 1.18 e$ \\
PC27 & $67.9 \pm 3.15 b$ & $51.5 \pm 3.89 d$ \\
PH5 & $71.4 \pm 1.36 b$ & $46.5 \pm 3.10 d e$ \\
PJ5 & $43.0 \pm 2.24 d$ & $37.8 \pm 1.34 e$ \\
PJ29 & $54.8 \pm 4.82 c$ & $31.3 \pm 1.39 f$ \\
PSC6 & $73.4 \pm 1.82 b$ & $53.9 \pm 3.54 d$ \\
PFC21 & $83.8 \pm 3.77 a$ & $59.4 \pm 2.18 c$ \\
Standard BHT & $84.5 \pm 2.54 a$ & $87.8 \pm 1.37 a$ \\
Standard vit. C & $83.7 \pm 2.48 a$ & $78.9 \pm 1.96 b$ \\
& \multicolumn{2}{c}{ ANOVA table } \\
S.E.M. & 2.01 & 1.62 \\
F-test & $*$ & $*$ \\
CD & 5.94 & 4.78 \\
\%CV & 5.43 & 6.43 \\
\hline
\end{tabular}

Values expressed are mean \pm S.E.M; $a, b, c, d, e, f$ : values with different superscripts differ significantly $(\mathrm{P}<0.05)$ in each rows \& columns

Among all ten isolates, PFC21 (sauerkraut isolate) could be considered as the most appropriate for preparing fermented product with high antioxidative property, as it showed maximum free radical scavenging ability using both ABTS $(83.8 \pm 3.77 \%)$ and DPPH $(59.4 \pm 2.18 \%$ ) assays followed by standards, vitamin C, and BHT. Similarly, PD2 (dosa batter isolate) displayed $79.4 \pm 1.61 \%$ scavenging activity with ABTS (non-significant with PFC21 and standards). Three isolates, i.e. PSC6 (53.9 \pm 3.54$)$, PC27 (51.5 \pm 3.89$)$ and PD2 (49.4 \pm 1.38$)$, exhibited similar trend (non-significant to each other) as confirmed using DPPH free radical assay. All isolates exhibited $>25 \%$ free radical scavenging activity following both methods; among all isolates, PFC21, PSC6, PD2, PC27, and PH5 showed very good antioxidant potential as compared to standards.

HATI and co-workers (2013) studied the antioxidative activity of probiotic lactobacilli in soy milk by ABTS method. L. rhamnosus C6 showed maximum antioxidative activity, i.e. percentage inhibition (97.0\%), followed by L. rhamnosus NCDC 19 (92.0\%), L. casei NCDC 17 (90.2\%), L. rhamnosus C2 (89.1\%), L. rhamnosus NCDC 24 (88.6\%), and L. casei NCDC 297 (88.0\%); besides, L. rhamnosus C6 strain also exhibited 50.2\% inhibition using DPPH assay. AfIFY and co-workers (2012) reported scavenging potential of the cell free extracts 
using ABTS assay; the maximum activity was observed with cell free extract of Probionebacterium freudenreichii $(84.7 \%)$ followed by L. rhamnosus $(84.6 \%)$ and L. reuteri (84.4\%). PUNIYA and co-workers (2016) reported highest inhibition of $85.8 \%$ and $78.8 \%$ against ABTS radical action with LH16 (human isolate) and LM13 (dairy isolate). These differences could be due to different proteolytic activity of individual cultures, which results in a release of antioxidative peptides (VIRTANEN et al., 2007).

\subsection{Proteolytic activity}

The extent of proteolysis varied among strains with incubation time. PD2 liberated highest amount of amino acids during $24 \mathrm{~h}$ and $48 \mathrm{~h}$ (i.e. 0.82 and $1.12 \mathrm{OD}$ values, respectively) of fermentation at $37^{\circ} \mathrm{C}$; followed by PC6 (0.99 OD) and PFC21 (0.90 OD) at $48 \mathrm{~h}$ incubation. For seven isolates, i.e. PD2, PD11, PC6, PC27, PH5, PSC6, and PFC21, the amount of liberated amino groups and peptides increased linearly till the end of fermentation (Table 3). These findings are consistent with those reported by LECLERC and co-workers (2002) using $L$. helveticus strains. Except PD30, PJ5, and PJ29 isolates, the amount of liberated amino groups and peptides increased only slightly during fermentation from 0 to $12 \mathrm{~h}$ for other isolates, but from 12 to $24 \mathrm{~h}$, these values increased significantly for all strains. Comparable growth pattern and proteolytic potential was observed by DONKOR and co-workers (2007) while studying L. acidophilus L10, L. acidophilus La 4962, B. lactis B94, B. longum B1536, L. casei L26, and L. casei Lc 279 . These findings were consistent with those reported by NIELSEN and co-workers (2001).

Table 3. Proteolytic activity of LAB isolates

\begin{tabular}{lccccc}
\hline \multirow{2}{*}{ LAB Isolates } & \multicolumn{5}{c}{ Absorbance at $340 \mathrm{~nm}$ at incubation time (hours) } \\
\cline { 2 - 6 } & 0 & 6 & 12 & 24 & 48 \\
\hline PD2 & $0.15 \pm 0.00 a b$ & $0.43 \pm 0.00 a$ & $0.53 \pm 0.02 a$ & $0.82 \pm 0.00 a$ & $1.12 \pm 0.00 a$ \\
PD11 & $0.12 \pm 0.00 c$ & $0.27 \pm 0.02 b c$ & $0.40 \pm 0.01 d$ & $0.44 \pm 0.00 i$ & $0.68 \pm 0.00 \mathrm{~h}$ \\
PD30 & $0.09 \pm 0.00 d$ & $0.16 \pm 0.02 d$ & $0.17 \pm 0.02 f$ & $0.65 \pm 0.00 i$ & $0.87 \pm 0.00 d$ \\
PC6 & $0.14 \pm 0.00 b$ & $0.38 \pm 0.00 a b$ & $0.45 \pm 0.00 c$ & $0.59 \pm 0.00 f$ & $0.99 \pm 0.00 b$ \\
PC27 & $0.16 \pm 0.00 a$ & $0.45 \pm 0.02 a$ & $0.51 \pm 0.00 b$ & $0.69 \pm 0.00 b$ & $0.86 \pm 0.00 e$ \\
PH5 & $0.16 \pm 0.00 a$ & $0.4 \pm 0.01 a$ & $0.54 \pm 0.03 a$ & $0.54 \pm 0.00 h$ & $0.73 \pm 0.00 g$ \\
PJ5 & $0.11 \pm 0.01 c$ & $0.22 \pm 0.04 c$ & $0.27 \pm 0.00 e$ & $0.44 \pm 0.00 i$ & $0.86 \pm 0.00 e$ \\
PJ29 & $0.08 \pm 0.00 d$ & $0.25 \pm 0.02 c$ & $0.29 \pm 0.00 e$ & $0.58 \pm 0.00 g$ & $0.63 \pm 0.00 i$ \\
PSC6 & $0.14 \pm 0.00 b$ & $0.33 \pm 0.03 b$ & $0.56 \pm 0.00 a$ & $0.63 \pm 0.00 e$ & $0.78 \pm 0.00 f$ \\
PFC21 & $0.17 \pm 0.00 a$ & $0.36 \pm 0.01 b$ & $0.51 \pm 0.00 b$ & $0.66 \pm 0.00 c$ & $0.90 \pm 0.00 c$ \\
& & & ANOVA table & & \\
S.E.M. & 0.00 & 0.02 & 0.01 & 0.00 & 0.00 \\
F-test & $*$ & $*$ & $*$ & $*$ & $*$ \\
CD & 0.01 & 0.05 & 0.03 & 0.01 & 0.01 \\
\%CV & 5.75 & 9.63 & 4.26 & 0.69 & 0.62 \\
\hline
\end{tabular}

Values expressed are mean \pm S.E.M; $a, b, c, d, e, f:$ values with different superscripts differ significantly $(\mathrm{P}<0.05)$ in each rows \& columns 
The proteolytic pattern certainly had a strong effect on bacterial growth. In this context, PD30 (dosa batter isolate) exhibited very slow growth in the fermentative medium but still showed good proteolytic activity at $48 \mathrm{~h}$ of incubation; it was insignificant with fast growing culture PFC21 (fermented cabbage isolate). In a similar assay, L. delbrueckii ssp. bulgaricus Lb 1466 exhibited poor growth, though showed appreciable peptidase activity. It indicated that this organism might require some other growth factors in addition to free amino acids and peptides (DonKor et al., 2005). In another study, L. rhamnosus NS4 liberated the highest amount of amino acids during $24 \mathrm{~h}$ of fermentation at $37^{\circ} \mathrm{C}(79.7 \%$ ACE inhibitory activity) followed by L. delbrueckii 009 (67.1\%) due to their strong proteolytic systems compared to the other isolates (HATI et al., 2015).

\subsection{ACE inhibitory activity}

ACE-inhibitory peptides can be produced by enzymatic hydrolysis of the milk proteins during the fermentation of milk with specific strains of LAB having antihypertensive activity. We have attempted to isolate $\mathrm{LAB}$ strains having potential to exhibit ACE-inhibition (Table 4). $\mathrm{PD} 2$ strain exhibited significantly $(\mathrm{P}<0.05)$ the highest $(49.4 \%) \mathrm{ACE}$ inhibition followed by PFC21 (41.4\%). PC27 (37.1\%) and PSC6 (33.8\%) isolates showed almost similar ACE inhibitory activity $(\mathrm{P}>0.05)$. All other isolates were found to exhibit ACE inhibitory profile ranging from $29.3-12.6 \%$. The lowest inhibition was reported for PD30 (12.6\%).

Table 4. ACE inhibition (\%) by LAB isolates in skim milk

\begin{tabular}{lc}
\hline LAB isolates & ACE inhibition $(\%)$ \\
\hline PD2 & $49.4 \pm 1.47 a$ \\
PD11 & $23.9 \pm 0.87 d e$ \\
PD30 & $12.6 \pm 0.62 g$ \\
PC6 & $26.4 \pm 1.73 d$ \\
PC27 & $37.1 \pm 1.47 c$ \\
PH5 & $29.3 \pm 2.31 d$ \\
PJ5 & $18.0 \pm 0.35 f$ \\
PJ29 & $21.2 \pm 2.09 e$ \\
PSC6 & $33.8 \pm 2.28 c$ \\
PFC21 & $41.4 \pm 1.07 b$ \\
& \\
S.E.M. & \\
F-test & 1.11 \\
CD & $*$ \\
\%CV & 3.28 \\
\hline
\end{tabular}

Values expressed are mean \pm S.E.M; $a, b, c, d, e, f$ : values with different superscripts differ significantly $(\mathrm{P}<0.05)$ in each rows

Two strains, L. rhamnosus NS4 and L. bulgaricus 009, gave maximum ACE inhibitory activity, i.e. $79.7 \%$ and $67.1 \%$, respectively, compared to other isolates (SolANKI, 2014). ACE inhibition profile of $L$. helveticus strain was evaluated in three media spectrophotometrically, where the lowest ACE inhibitory activity was obtained for WPI-enriched milk (2.24-3.51 $\mathrm{mg} \mathrm{ml}^{-1}$ ) hydrolysis (YАмамото et al., 1994). Higher ACE inhibitory activity was measured 
for skim milk medium $\left(1.15-1.68 \mathrm{mg} \mathrm{ml}^{-1}\right)$, whereas caseinate enriched milk provided the highest ACE inhibitory activity $\left(0.6-1.1 \mathrm{mg} \mathrm{ml}^{-1}\right)$. Results indicate that proteolysis by starter bacteria is indispensable to generate ACE inhibitors in fermented milks. Also, the nature of protein substrate used in the medium was found to be more important in the production of ACE inhibitors than the degree of protein.

\section{Conclusions}

Traditional fermented foods had emerged as rich sources of probiotic LAB. Outcomes of the present work indicate that LAB strains isolated from traditional Indian fermented foods showed excellent antioxidative potential, proteolytic and antihypertensive attributes in addition to previously proven probiotic potential. Starters with such vital characteristics can help to develop functional probiotic food with a wide range of health benefits. However, it warrants further in vitro and in vivo studies to elucidate the potential therapeutic benefits of isolated lactic acid bacteria strains.

\section{References}

Afify, M.R., Romeilah, R.M., Sultan, S.I.M. \& Hussein, M.M. (2012): Antioxidant activity and biological evaluations of probiotic bacteria strains. Int. J. Acad. Res. (IJAR), 4, 131-139.

CHeung, H.S. (1971): Spectrophotometric assay and properties of the angiotensin-converting enzyme of rabbit lung. Biochem. Pharmacol., 20, 1637-1648.

Chtourou, Y., Trabelsi, K., Fetoui, H., Mkannez, G., Kallel, H. \& Zeghal, N. (2011): Manganese induces oxidative stress, redox state unbalance and disrupts membrane bound ATPases on murine neuroblastoma cells in vitro: Protective role of silymarin. Neurochem. Res., 36, 1546-1557.

Donkor, O.N., Henriksson, A., Vasiljevic, T. \& Shah, N.P. (2005): Proteolytic activity of dairy lactic acid bacteria and probiotics as determinant of viability and in vitro angiotensin-converting enzyme inhibitory activity in fermented milk. Lait, 87, 21-38.

Donkor, O.N., Henriksson, A., VAsilJeVIC, T. \& SHAH, N.P. (2007): Rheological properties and sensory characteristics of set-type soy yogurt. J. Agr. Food Chem., 55, 9868-9876.

FitzGerald, R.J. \& Meisel, H. (2000): Milk protein-derived peptides inhibitors of angiotensin-I-converting enzyme. Brit. J. Nutr., 84, 33-37.

Hati, S., Shilpa, V., BriJ, S., Vandana, K. \& Surjit, M. (2013): Antioxidant activity and polyphenol content in fermented soymilk supplemented with WPC-70 by probiotic lactobacilli. Int. Food Res. J. (IFRJ), 20, 21252131.

Hati, S., Sreeja, V., Solanki, J. \& Prajapati, J.B. (2015): Significance of proteolytic microorganisms on ACEinhibitory activity and release of bioactive peptides during fermentation of milk. Indian J. Dairy Sci., 68, 584-591.

Kholif, A.M., Mohron, G.A., El-Nawawy, M.A., Ismail, A.A. \& Salem, M.M.E. (2011): Evaluation of proteolytic activity of some dairy lactobacilli. World J. Dairy Food Sci., 6, 21-26.

Leclerc, P.L., Gauthier, S.F., Bachelard, H., Santure, M. \& Roy, D. (2002): Antihypertensive activity of caseinenriched milk fermented by Lactobacillus helveticus. Int. Dairy J., 12, 995-1004.

Mishra, V., Shah, C., Mokashe, N., Chavan, R., Yadav, H. \& Prajapati, J. (2015): Probiotics as potential antioxidants: a systematic review. J. Agr. Food Chem., 63, 3615-3626.

Nielsen, P.M., Petersen, D. \& Dambmann, C. (2001): Improved method for determining food protein degree of hydrolysis. J. Food Sci., 66, 642-646.

Papadimitriou, M.N., Resende, C. \& Kuchler, K. (2007): High Pdr12 levels in spoilage yeast Saccharomyces cerevisiae, correlate directly with sorbic acid levels in the culture medium but are not sufficient to provide cells with acquired resistance to the food preservative. Int. J. Food Microbiol., 11, 173-179.

Puniya, M., Kumar, R.M., Panwar, H., Kumar, N., Ramneek \& Kumar, A.P. (2016): Screening of lactic acid bacteria of different origin for their probiotic potential. J. Food Process Technol., 7, 545-553.

Acta Alimentaria 47, 2018 
Re, R., Pellegrini, N., Proteggente, A., Pannala, A., Yang, M. \& Rice-Evans, C. (1999): Antioxidant activity applying an improved ABTS radical cation decolorization assay. Free Radic. Bio. Med., 26, 1231-1237.

SolAnkI, J. (2014): Screening of lactic acid bacteria on the basis of ACE inhibitory activity. M.B. Patel Science College, Anand, Gujarat, India, M.Sc. Thesis. pp. 5-15.

Spyropoulos, B.G., Evangelos, P.M., Constantine, F. \& Christos, N.S. (2011): Antioxidant properties of probiotics and their protective effects in the pathogenesis of radiation-induced enteritis and colitis. Digest. Dis. Sci., 56, 285-294.

Thakkar, P.N., Modi, H.A. \& Prajapati, J.B. (2015): Isolation, characterization and safety assessment of lactic acid bacterial isolates from fermented food products. Int. J. Curr. Microbiol. Appl. Sci. (IJCMAS), 4, 713-725.

Virtanen, T., Pihlanto, A., Akkanen, S. \& Korhonen, H. (2007): Development of antioxidant activity in milk whey during fermentation with lactic acid bacteria. J. Appl. Microbiol., 10, 106-115.

Yamamoto, N., Aкino, A. \& Takano, T. (1994): Antihypertensive effect of the peptides derived from casein by an extracellular proteinase from Lactobacillus helveticus CP790. J. Dairy Sci., 77, 917-922.

Yoshikawa, M., Fujita, H., Matoba, N., Takenaka, Y., Yamamoto, T. \& Yamauchi, R. (2000): Bioactive peptides derived from food proteins preventing lifestyle-related diseases. BioFactors, 12, 143-146. 